\title{
Continuity and change in Romanian societal culture dimensions*
}

\section{Doina Catana, Gheorghe Alexandru Catana ${ }^{* *}$}

Our study contributes to the literature about societal culture dimensions, as reflected by the perceptions and expectations of students and present managers. We find some similarities but also statistically significant differences between students and middle managers in Romania in terms of their perception on nine societal culture practices as well as their expectations about societal culture values. The research sample consists of 427 undergraduate and graduate students in engineering and business and 216 middle managers. Our results show similarities in perceptions of society's future orientation, institutional collectivism and assertiveness and significant differences in perception of the other six cultural practices. Similarities in expectations (values) were also noted concerning gender egalitarianism and assertiveness.

Unsere Studie liefert einen Beitrag zur Literatur über Nationalkulturen wie sie in den Sichtweisen und Erwartungen von Studenten und derzeitigen Führungskräften reflektiert werden. Wir fanden einige Übereinstimmungen, aber auch statistisch signifikante Unterschiede zwischen Studenten und mittleren Führungskräften in Rumänien bezüglich ihrer Sichtweisen auf neun kulturelle Werte. Das Sample bestand aus 427 Studenten ohne und mit Abschluss in Ingenieurwissenschaft und Betriebswissenschaft und 216 mittleren Führungskräften. Unsere Ergebnisse zeigen Übereinstimmungen in Sichtweisen auf die gesellschaftliche Zukunftsorientierung, den institutionellen Kollektivismus und die Selbstbehauptung, und signifikante Unterschiede in Hinblick auf die sechs anderen kulturellen Praktiken. Übereinstimmungen in Erwartungen (Werte) gab es auch betreffend geschlechtlichem Egalitarismus und Selbstbehauptung.

Key words: GLOBE, societal culture, cultural practice, cultural value

Manuscript received: 13.03.11, accepted: 04.03.12 (1 revision)

** Doina Catană, Prof., Department of Electrical Machines, Marketing and Management, Technical University of Cluj-Napoca, Romania. Main research areas: Organizational culture, leadership and marketing. Corresponding address: dcatana@mae.utcluj.ro

Gheorghe-Alexandru Catană, Prof., Department of Electrical Machines, Marketing and Management, Technical University of Cluj-Napoca, Romania. Main research areas: Organizational culture, leadership and marketing. 


\section{Introduction}

This article addresses the question of continuity and change of societal cultural practices and values in Romania by comparing samples of students and middle managers on the nine dimensions of culture used in the GLOBE international research project.

The surveys carried out among middle managers in 61 countries by GLOBE project researchers distinguished the extent to which the cultural practices and values of business managers are universal vs. country or country cluster specific (House et al. 2004: 3). Building on and aiming to extend the GLOBE findings, the GLOBE STUDENT project was initiated in $2008^{10}$. Seven Central and East European countries have joined the project to date (Austria, Czech Republic, Germany, Poland, Romania, Slovakia and Slovenia). The project focuses on prospective managers' perceptions of currrent cultural practices and their aspirations in this respect. It assumes that future managers will be recruited mainly from students in business and engineering, therefore $95 \%$ of the Central and East European sample comes from these two fields. The GLOBE STUDENT project has several objectives, among which to distinguish the profile of the average prospective manager from the survey respondents' perceptions and expectations regarding societal culture dimensions, to explore the extent to which differences in perceptions are country specific, and conjecture on the probability of future convergence among these variables.

In comparing the student sample with the cultural profile of the average Romanian middle manager, our study uses GLOBE STUDENT and GLOBE II country specific data. We find evidence that supports the hypothesis that, both junior and senior generations within the society share common practices and values, experienced through primary and secondary forms of socialization ${ }^{11}$. At the same time, given that cultures do change under the influence of internal and external factors (Ferraro 1994), we would like to assess the direction of desired changes in Romanian culture, by using $A s$ it is scales (i.e., societal practice or perceptions of one's society) and As it should be scales (i.e., espoused values concerning one's ideal society). Specifically, we will try to answer the following questions using Romanian survey data:

10 The project is coordinated by R. Lang from Chemnitz University of Technology

11 In our opinion, primary socialization reflects the early home formative years (in Romanian culture, the first 6 years spent at home), secondary socialization results from interaction within public and private institutions (school, friends, church, army, mass media, membership clubs etc.), while "tertiary" socialization is the professional, experienced through practicing one's occupation (students' perceptions and values are, for sure influenced by their socializing factors, such as family/parents/friends, educators/professors, sport, movie and music stars, or scientific role models) 
1. Are there any differences between students' perceptions of current societal practices and their expectations (of societalal values)?

2. Are there any differences between middle managers' perceptions of current societal practices and their expectations (societal values)?

3. Are there any differences between student perceptions of actual societal practices and those of middle managers?

4. To what extent do students' societal values (expectations) differ from those of middle managers?

Our findings are conditional on the following:

1. The students' perceptions and values are dynamic and likely to change annually); we control for this by having more than $80 \%$ of our sample comprising students in their last semester of bachelor and master studies (i.e. ready to enter the labour force).

2. The students do not have experience in managerial practices, thus their present perceptions and values will not necessarily be identical with the future ones, especially as peer, membership groups and occupational socialization will clearly impact their value system.

3. The characterization of the average manager does not reveal differences between younger and elder managers, as generated by duration of their career, and the distinct generational experiences with respect to changes in Romanian society and globalization. Still we might consider the findings about managers' sample as being strongly influenced by the younger managers (55.5\% of the managers are 22 to 40 years old).

4. Although results suggest that younger generations could bring changes to the Romanian value system, we are naturally aware that the complexity of issues related to culture continuity and change across different generations goes beyond direct statistical analysis.

\section{Theoretical background}

It is well known that no single generally accepted definition of societal culture exists (Chhokar et al. 2007:3). Our study uses the definition of the GLOBE international research project: "shared motives, values, beliefs, identities and events that result from common experiences of members of collectives and are transmitted across age generations" (House et al. 2002: 5). The GLOBE project distinguishes between practices (As it is) and values (As it should be), but this distinction is a relative one. Values distinguishing one culture from another are predictors for future cultural practices, as well as for the features of leadership and behaviour in that culture (House et al. 2002). In all societies, the shared values become good future practices. 
The GLOBE approach to culture has a psychological/behavioural foundation which assumes that shared values are incorporated in behaviour, policies and practices. In this approach, culture is operationalised in nine dimensions (House et al. 2004): 1. Uncertainty Avoidance (tendency towards order, a structured life through laws and rules, clear specification of social expectations etc;); 2. Future Orientation (degree to which future oriented behavior is encouraged and rewarded by society); 3. Power Distance (extent to which members of a society expect and agree that power should be distributed unequally); 4. Collectivism I or Institutional Collectivism (social encouragement and rewarding of collective distribution of resources and collective action). 5. Humane Orientation (social encouragement and rewarding of fairness, altruism, friendship, generosity, kindness and altruistic ideals in individuals' behavior); 6. Performance Orientation (encouragement and rewarding of behavior targeting success, performance improvement and excellence); 7. Collectivism II or Ingroup/Family Collectivism (expressions of pride, loyalty and cohesiveness in families and circles of close associates); 8. Gender Egalitarianism (minimization of gender differences and promotion of gender equity and equality); 9. Assertiveness (degree to which individuals are permitted to be confrontational and aggressive in their social relationships).

The GLOBE researchers acknowledge (House et al. 2002: 6) that Assertiveness, Collectivism I (Institutional Collectivism), Gender Egalitarianism, Power Distance and Uncertainty Avoidance are built on Hofstede's dimensions (Hofstede 1980), with Assertiveness and Gender Egalitarianism replacing Hofstede's Masculinity dimension. Collectivism II is derived from the work of Triandis (Triandis 1993), while the concepts of Future Orientation and Humane Orientation are drawn from the studies conducted by Kluckholn and Strodtbeck (1961), Putnam (1993) and McClelland (1985) and those on Performance Orientation from McClelland's research on implicit motivation and economic development (McClelland 1961, 1985).

As mentioned above, our research compares the cultural views of students in business and engineering with those held by the current average middle manager. The findings help in portraying the dynamics of societal culture. Accepting that values "high in centrality, pervasive, and supported by powerful sanctions and high consensus" (Williams 1979: 34) are resistant to change (reflecting cultural continuity), we are also aware that changes do occur as one generation succeeds another (Keating et al. 2002: 637). This is why we expect to discover significant differences between the perceived practices and the values that Romanian students aspire to. Axiologically speaking, the values they aspire to will likely become their future practices and behavioural patterns as managers and leaders.

To our knowledge, only one empirical research has tested potential differences in the perceptions of students and managers using GLOBE research instruments 
(Keating et al. 2002). This study (focusing on Austria and Ireland) found a strong cohort (age) effect for two cultural practices: Collectivism II (students gave lower scores than managers) and Gender Egalitarianism (students gave higher scores in both countries). It also found strong cohort effect for Collectivism I, Future Orientation and Power Distance values (students scored lower than the managers) (Keating et al. 2002: 642).

This research results suggest that we should not expect differences between students and middle managers perceptions in all of the nine cultural practices and values. At the same time, considering the internal and external factors influencing Romania in the last decades, such as the collapse of the communist regime and European Union integration, as well as the students' exposure to international exchange programs, Western teaching materials, movies, TV channels or virtual communities via Internet, we might expect to find significant differences between the analyzed samples with respect to some perceptions and expectations.

\section{Methodological framework}

Our study uses section 1 and section 3 of the GLOBE research project Beta questionnaire (House et al. 2004). Culture dimensions have been measured using the scales in section 1 (As it is), asking the subjects to value the way our society is (practices) and, respectively, section 3 (As should be), asking opinion about the way our society should be (values). The student population was defined as engineering and business students, studying in three Romanian universities. Business and engineering students were chosen based on GLOBE STUDENT project assumption that a large portion of the future generation of middle managers will come from these two fields of study. The sample consists of 427 students, out of which $52.7 \%$ were male and $47.3 \%$ female; $38.9 \%$ of them are studying business/management and $61.1 \%$, engineering; $64.6 \%$ are enrolled in bachelor, and $35.4 \%$ in master level programs. The surveys were carried out beteeen November 2008 and April 2009.

The sample of middle managers consists of 216 subjects from three fields of activity: food, telecommunication and financial services. It consists of $48.1 \%$ males and $51.9 \%$ females with most of them having business or engineering educational background (81.9\%). Most of them have up to 10 years of seniority in management positions (79.6\%). As for the sample age structure, 13\% are 51 and above, $31.5 \%$ are 41 to 50 years old, $35.6 \%$ belong to 31 to 40 group and $19.9 \%$ are the youngest ( 22 to 30 years old).

The surveys were carried out beteeen 2007 and $2009^{12}$.

12 A part of the data about middle managers has been collected by members of COLEAD (Organizational Culture and Leadership Association, Romania) 
Figure 1 depicts the samples structure based upon the subjects' educational background.

Figure 1: Education area/background of students and middle managers

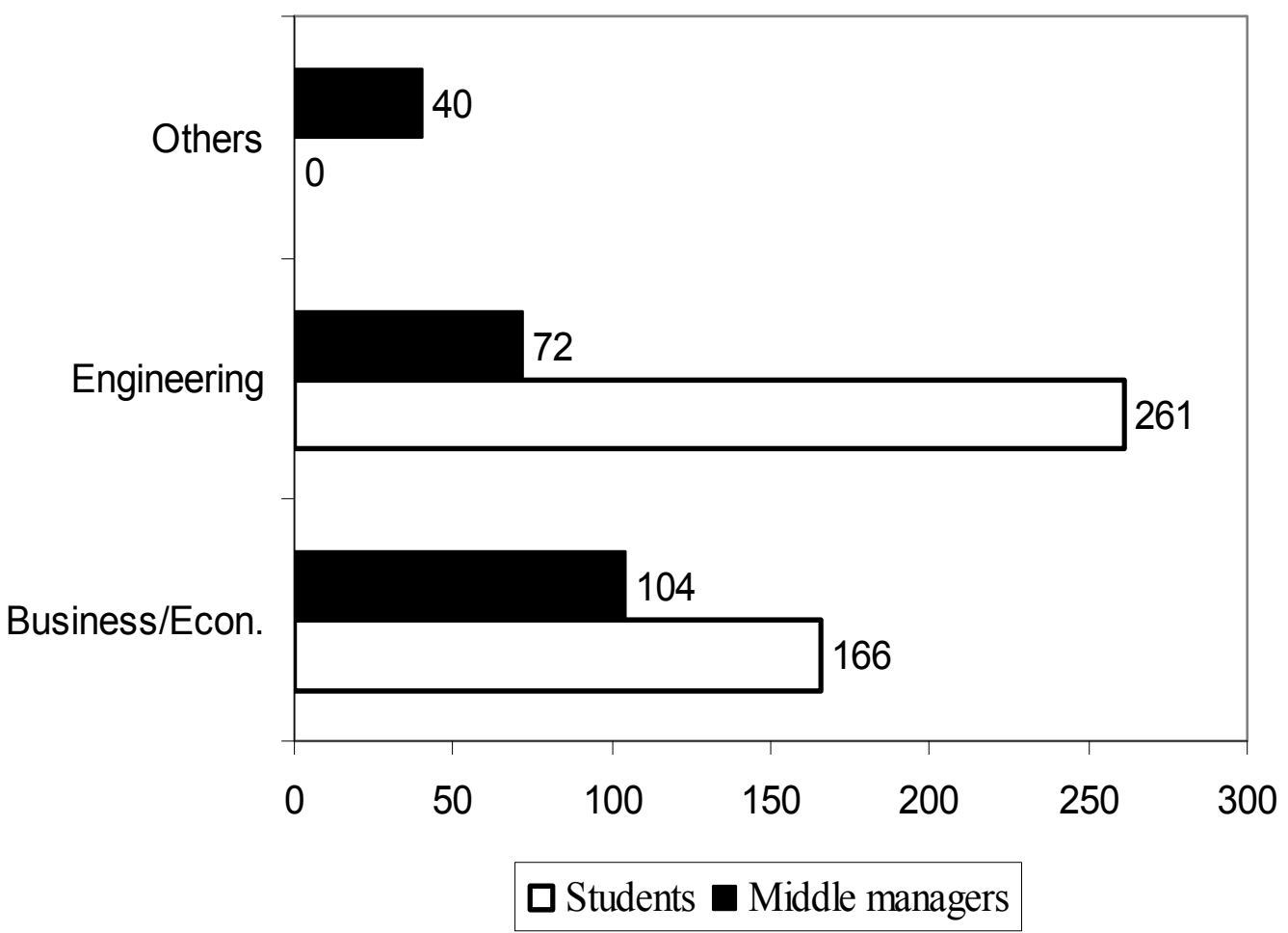

The empirical data was processed with SPSS 17 with the descriptive statistical analysis carried out separately for students and middle managers. In order to test the statistical significance in the mean values of the differences between societal practices (As it is variables) and societal values (As it should be variables) in the two samples, we employed the paired-samples t-test, using the 0.05 significance threshold. In comparing the student sample with the middle managers, the independent samples $t$-test was used, with 0.05 significance threshold. The research results are presented and discussed in the following paragraphs.

\section{Research findings}

The research findings concern: 1 . the differences between students' perceptions of current cultural practices and desired ones (values); 2. differences between middle managers' perceptions of current cultural practices and desired ones (values); 3 . differences between students' and middle managers perception of societal practices; 4. differences between students' and middle managers expectations concerning societal values. 


\section{Differences between societal practices and values: student sample}

The significant differences between cultural practices and values for the nine cultural dimensions in student sample are shown in Table 1, while the differences in the mean values of cultural practice and expectations in Figure 2.

Table 1: Significant differences between perceived cultural practices and cultural expectations in student sample*

\begin{tabular}{|c|c|c|c|c|c|}
\hline \multirow[t]{2}{*}{ Societal culture dimension } & \multicolumn{2}{|c|}{$\begin{array}{l}\text { Practice } \\
\text { (as it is) }\end{array}$} & \multicolumn{2}{|c|}{$\begin{array}{c}\text { Value } \\
\text { (as it should be) }\end{array}$} & \multirow{2}{*}{$\begin{array}{l}\text { t-test } \\
\text { (sig 2- } \\
\text { tailed) }\end{array}$} \\
\hline & Rank & Mean & Rank & Mean & \\
\hline Uncertainty Avoidance & 8 & 3.49 & 5 & 5.10 & $\begin{array}{l}-29.540 \\
(.000)\end{array}$ \\
\hline Future Orientation & 9 & 3.44 & 4 & 5.23 & $\begin{array}{c}-26.782 \\
(.000)\end{array}$ \\
\hline Power Distance & 1 & 5.81 & 9 & 2.65 & $\begin{array}{l}51.366 \\
(.000)\end{array}$ \\
\hline $\begin{array}{l}\text { Collectivism } \\
\text { (Institutional) }\end{array}$ & 5 & 3.78 & 6 & 4.94 & $\begin{array}{l}-19.058 \\
(.000)\end{array}$ \\
\hline Humane Orientation & 4 & 3.83 & 3 & 5.41 & $\begin{array}{r}-29.147 \\
(.000)\end{array}$ \\
\hline Performance Orientation & 6 & 3.66 & 1 & 5.89 & $\begin{array}{c}-37.396 \\
(.000)\end{array}$ \\
\hline $\begin{array}{l}\begin{array}{l}\text { Collectivism } \\
\text { group/Family) }\end{array} \\
\text { II }\end{array}$ & 2 & 5.13 & 2 & 5.70 & $\begin{array}{c}-11.339 \\
(.000)\end{array}$ \\
\hline Gender Egalitarianism & 3 & 3.99 & 7 & 4.42 & $\begin{array}{c}-11.244 \\
(.000)\end{array}$ \\
\hline Assertiveness & 7 & 3.51 & 8 & 4.01 & $\begin{array}{l}-8.770 \\
(.000)\end{array}$ \\
\hline
\end{tabular}

*paired samples, t-test 
Figure 2: Differences between perceptions and expectations: student sample (mean values)

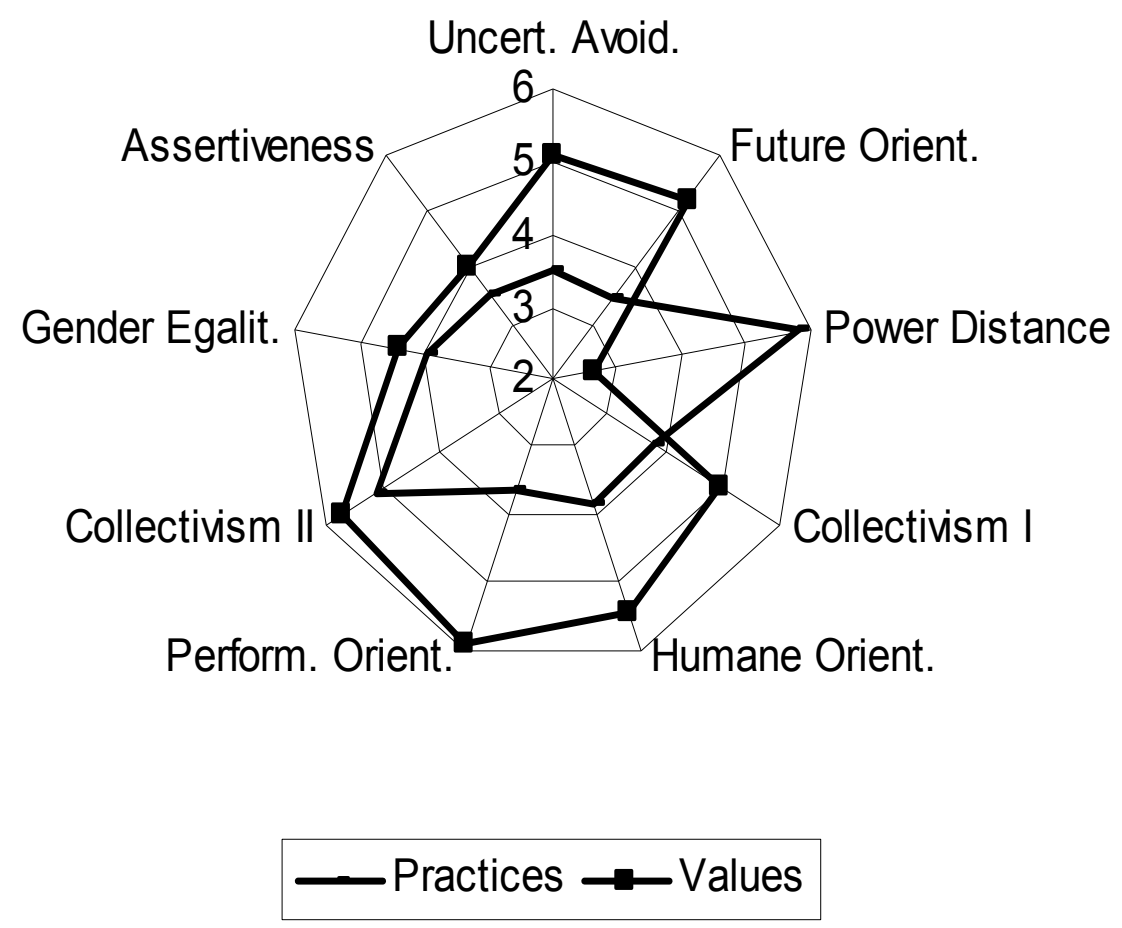

Notice: To make the differences more tangible, the scale of web chart spreads from 2 to 6

As seen in Table 1, the Romanian average student perceives our society as having high instances of Power Distance (highest mean value), In group/Family Collectivism (Collectivism II), fair treatment of two genders, and fair Humane Orientation. On the other hand, students perceive the Romanian society as being lower in Future Orientation ( $9^{\text {th }}$ place), Uncertainty Avoidance $\left(8^{\text {th }}\right)$ and Assertiveness ( $7^{\text {th }}$ place).

In terms of expectations, the average student desires a society with a strong Performance Orientation (highest mean score), preservation of tight Family/In group relationships and Humane Orientation, as well as a stronger Future Orientation.

The highest difference between perceptions of current practices and an ideal enviroment was noted for Power Distance $(t=51.366$; $\mathrm{sig}=0.000)$ which suggests that the students would like to live in a society with less than half of the present (perceived) Power Distance (i.e. in a more democratic setting). Very high differences were also recorded for Performance Orientation $(\mathrm{t}=37.396$; sig $=0.000)$, Uncertainty Avoidance $(\mathrm{t}=29.540 ; \mathrm{sig}=0.000)$, Humane Orientation $(\mathrm{t}=29.147 ; \mathrm{sig}=0.000)$ and Future Orientation $(\mathrm{t}=26.782 ; \mathrm{sig}=0.000)$. 
Table 2 displays the statistically significant differences along with student sample main demographic characteristics: gender, field of study, level of study (bachelor and master).

Table 2: Student sample demographics and significant differences in cultural dimensions

\begin{tabular}{|c|c|c|c|c|c|}
\hline Culture dimension & $\begin{array}{l}\text { Sample } \\
\text { mean }\end{array}$ & $\begin{array}{l}\text { Standard } \\
\text { deviation }\end{array}$ & $\begin{array}{l}\text { Mean } \\
\text { (G1) }\end{array}$ & $\begin{array}{c}\text { Mean } \\
(G 2)\end{array}$ & t-test (sign.)* \\
\hline \multicolumn{6}{|c|}{ GENDER $($ G1=female; $n=237 ; \mathbf{G 2}=$ male; $n=190)$} \\
\hline \multicolumn{6}{|l|}{ Practices } \\
\hline $\begin{array}{l}\text { a. Gender } \\
\text { Egalitarianism }\end{array}$ & 3.99 & 0.674 & 3.93 & 4.06 & $\begin{array}{l}(-) 2.072 \\
(0.039)\end{array}$ \\
\hline \multicolumn{6}{|l|}{ Values } \\
\hline a. Collectivism I & 4.94 & 0.751 & 4.85 & 5.04 & $\begin{array}{l}(-) 2.724 \\
(0.007)\end{array}$ \\
\hline b. Assertiveness & 4.01 & 0.745 & 3.94 & 4.09 & $\begin{array}{l}(-) 2.144 \\
(0.033)\end{array}$ \\
\hline \multicolumn{6}{|c|}{$\begin{array}{l}\text { FIELD OF STUDY (G1=Business/Economics; } n=166 ; \\
\text { G2=Engineering; } n=261)\end{array}$} \\
\hline \multicolumn{6}{|l|}{ Practices } \\
\hline a. Collectivism II & 5.13 & 0.779 & 5.25 & 5.05 & $\begin{array}{l}2.498 \\
(0.013)\end{array}$ \\
\hline \multicolumn{6}{|l|}{ Values } \\
\hline $\begin{array}{l}\text { a. Performance } \\
\text { Orientation }\end{array}$ & 5.89 & 0.708 & 5.77 & 5.97 & $\begin{array}{l}(-) 2.910 \\
(0.004)\end{array}$ \\
\hline $\begin{array}{l}\text { b. Gender } \\
\text { Egalitarianism }\end{array}$ & 4.42 & 0.567 & 4.34 & 4.46 & $\begin{array}{l}(-) 2.202 \\
(0.028)\end{array}$ \\
\hline \multicolumn{6}{|c|}{ LEVEL OF STUDY (G1= Bachelor; $n=276 ;$ G2= Master; $n=151)$} \\
\hline \multicolumn{6}{|l|}{ Practices } \\
\hline $\begin{array}{l}\text { a. Performance } \\
\text { Orientation }\end{array}$ & 3.66 & 0.999 & 3.75 & 3.49 & $\begin{array}{l}2.670 \\
(0.008)\end{array}$ \\
\hline $\begin{array}{l}\text { b. Gender } \\
\text { Egalitarianism }\end{array}$ & 3.99 & 0.674 & 4.07 & 3.83 & $\begin{array}{l}3.626^{*} \\
(0.000)\end{array}$ \\
\hline
\end{tabular}




\begin{tabular}{|l|l|l|l|l|l|}
\hline \multicolumn{2}{|l|}{ Values } \\
\hline $\begin{array}{l}\text { a. Uncertainty } \\
\text { Avoidance }\end{array}$ & 5.10 & 0.765 & 5.18 & 4.96 & $\begin{array}{l}2.854 \\
(0.005)\end{array}$ \\
\hline $\begin{array}{l}\text { b. Humane Orientation } \\
\text { c. Performance } \\
\text { Orientation }\end{array}$ & 5.41 & 0.770 & 5.46 & 5.31 & $\begin{array}{l}1.973 \\
(0.049)\end{array}$ \\
\hline
\end{tabular}

* 2 - tailed significance; only statistical significant $(\mathrm{p}<0.05)$ differences are shown

As for differences between genders, the results show only one significant difference in practice perception (Gender Egalitarianism), with a lower mean score recorded in the female group (this group being majoritar in the sample). With respect of group expectations, males desire a higher In group/Family Collectivism and Assertiveness than the female students $(\mathrm{t}=2.724$; sig $=0.007$ for In group Collectivism, respectivelly, $\mathrm{t}=2.144$; $\mathrm{sig}=0.033$ for Assertiveness).

We should mention that there is only one statisticaly significant difference between the perceptions of students in business and in engineering: Collectivism II ( $\mathrm{t}=2.498$; sig $=0.013$, equal variances assumed $)$. In the case of expectations, the differences concern: Performance Orientation $(\mathrm{t}=2.910$; $\mathrm{sig}=$ 0.004 ; equal variance assumed $)$ and Gender Egalitarianism $(\mathrm{t}=2.202$; $\mathrm{sig}=$ 0.028; equal variance assumed). These findings give us support for believing that the body of future managers will have a similar approach in cultural practices and values.

With regard to difference between undergraduate and postgraduate students, the results show two significant differences in practice perceptions: Performance Orientation and Gender Egalitarianism, in both cases bachelor students considering these dimensions as being present in our society to a higher degree than master level students. As for cultural expectations, bachelor students desire higher societal concern for avoiding uncertainty and humanitarianism $(\mathrm{t}=$ 2.854; $\mathrm{sig}=0.005$, respectivelly, $\mathrm{t}=1.973$; $\mathrm{sig}=0.049)$, while master level students would like a higher Performance Orientation of our society $(\mathrm{t}=2.350$; $\operatorname{sig}=0.019)$.

\section{Differences between societal practices and values: middle managers sample}

The significant differences between managerial perceptions of cultural practices and the cultural expectations are summarized in Table 3 and illustrated in Figure 3. 
Table 3: Significant differences between perceived cultural practices and cultural expectations in middle managers sample*

\begin{tabular}{|l|c|c|c|c|r|}
\hline \multirow{2}{*}{ Societal culture dimension } & \multicolumn{2}{|c|}{$\begin{array}{c}\text { Practice } \\
\text { (as it is) }\end{array}$} & \multicolumn{2}{c|}{$\begin{array}{c}\text { Value } \\
\text { as it should } \\
\text { be) }\end{array}$} & $\begin{array}{r}\text { t-test } \\
\text { (sig 2-tailed) }\end{array}$ \\
\cline { 2 - 5 } & Rank & Mean & Rank & Mean & \\
\hline Uncertainty Avoidance & 3 & 3.92 & 9 & 3.58 & $\begin{array}{r}2.360 \\
(0.019)\end{array}$ \\
\hline Future Orientation & 8 & 3.41 & 6 & 4.06 & $\begin{array}{r}-5.291 \\
(0.000)\end{array}$ \\
\hline Power Distance & 1 & 4.06 & 7 & 3.69 & $\begin{array}{r}2.267 \\
(0.024)\end{array}$ \\
\hline Collectivism (Institutional) & 5 & 3.73 & 4 & 4.17 & $\begin{array}{r}-5.054 \\
(0.000)\end{array}$ \\
\hline Humane Orientation & 2 & 4.04 & 8 & 3.62 & $\begin{array}{r}3.969 \\
(0.000)\end{array}$ \\
\hline Performance Orientation & 3 & 3.92 & 3 & 4.25 & -2.107 \\
& & & & & $(0.036)$ \\
\hline $\begin{array}{l}\text { Collectivism II (In } \\
\text { group/Family) }\end{array}$ & 6 & 3.67 & 1 & 4.68 & $\begin{array}{r}-14.821 \\
(0.000)\end{array}$ \\
\hline Gender Egalitarianism & 4 & 3.86 & 2 & 4.49 & $\begin{array}{r}-11.037 \\
(0.000)\end{array}$ \\
\hline Assertiveness & 7 & 3.56 & 5 & 4.08 & -5.082 \\
& & & & & $(0.000)$ \\
\hline
\end{tabular}

*paired samples, t-test 
Figure 3: Differences between perceptions and expectations: middle managers sample (mean values)
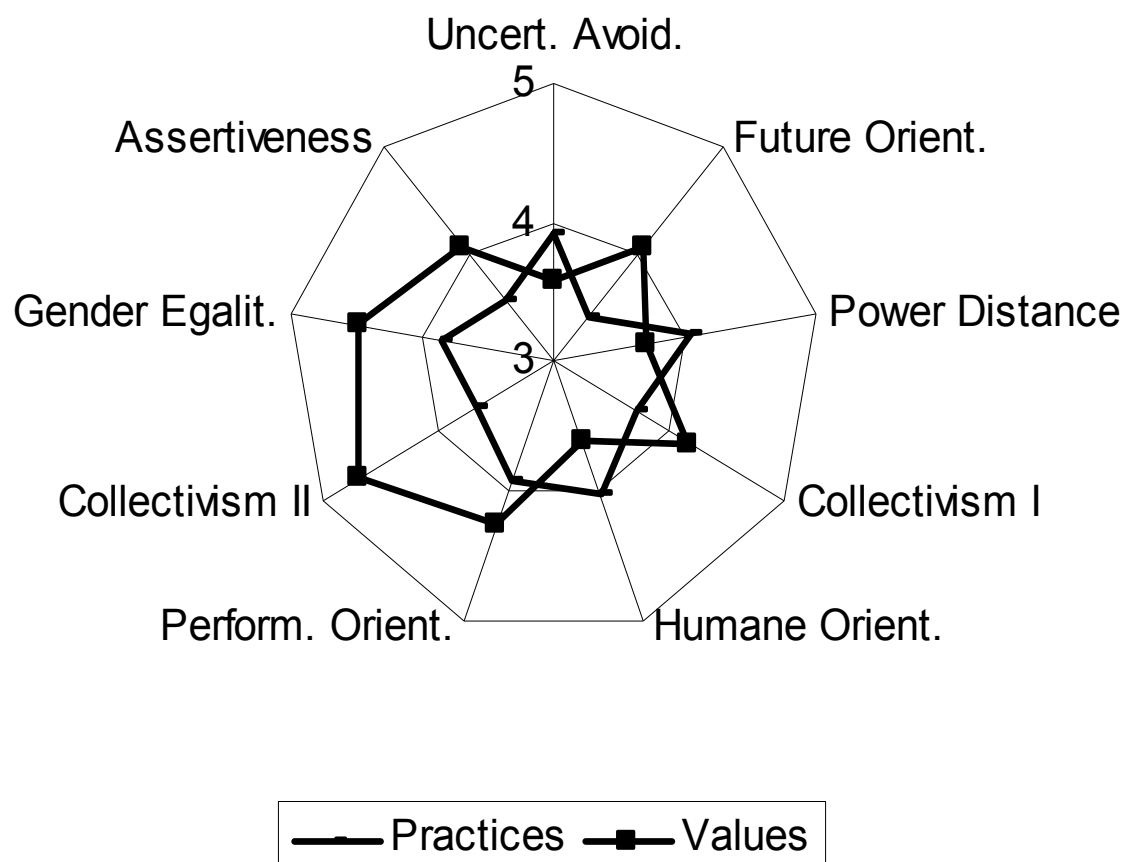

Notice: To make the differences more tangible, the scale of web chart spreads from 3 to 5

The average Romanian middle manager perceives Romanian society as having high Power Distance (highest mean value), followed by high Humane Orientation (above the middle point of the scale) and adequate levels of Uncertainty Avoidance and Performance Orientation (very close to the scale mid-point). On the lower end of the scale is the score of Future Orientation (the lowest overall score). Regarding expectations, the typical Romanian middle manager desires a society with strong Family/In group relationships, Gender Egalitarianism, Performance Orientation, Institutional Collectivism, Assertiveness and Future Orientation (mean values above the scale middle point). On the other side, he/she expects a decrease in Uncertainty avoidance, Humane orientation and Power Distance (mean values bellow the scale midpoint). The highest difference between the perceived and desired values was noted for Collectivism II $(\mathrm{t}=14.821$; sig $=0.000)$ which suggests that middle managers prefer a society with tighter Family/In group adhesiveness. A high difference was also recorded for Gender Egalitarianism $(\mathrm{t}=11.037$; sig $=$ 0.000 ), showing a desire to live in a society which promotes gender equity and equality. Alternatively, there are certain signs of desiring a decrease in society's Humane Orientation and Power Distance. 
Table 4 displays the statistically significant differences along the most important demographic characteristics of managers sample: gender, age groups, educational background, seniority in management positions.

Table 4: Managers sample demographics and significant differences in cultural dimensions

\begin{tabular}{|c|c|c|c|c|c|}
\hline Culture dimension & $\begin{array}{l}\text { Sample } \\
\text { mean }\end{array}$ & $\begin{array}{l}\text { Standard } \\
\text { deviation }\end{array}$ & $\begin{array}{l}\text { Mean } \\
\text { (G1) }\end{array}$ & $\begin{array}{c}\text { Mean } \\
(G 2)\end{array}$ & $t$-test (sign)* \\
\hline \multicolumn{6}{|c|}{$\begin{array}{l}\text { GENDER } \\
(\text { G1 = female; } n=112 ; G 2=\text { male } ; n=104)\end{array}$} \\
\hline \multicolumn{6}{|l|}{ Practices } \\
\hline a. Collectivism I & 3.73 & 0.752 & 3.62 & 3.86 & $\begin{array}{l}2.416 \\
(0.017)\end{array}$ \\
\hline \multicolumn{6}{|l|}{ Values } \\
\hline $\begin{array}{l}\text { a. Gender } \\
\text { Egalitarianism }\end{array}$ & 4.49 & 0.648 & 4.63 & 4.34 & $\begin{array}{l}(-) 3.434 \\
(0.001)\end{array}$ \\
\hline \multicolumn{6}{|c|}{$\begin{array}{l}\text { AGE GROUPS } \\
(G 1=\text { up to } 40 \text { years; } n=120 ; G 2=>40 \text { years; } n=96)\end{array}$} \\
\hline \multicolumn{6}{|c|}{ Practices } \\
\hline \multicolumn{6}{|c|}{ No significant differences } \\
\hline \multicolumn{6}{|l|}{ Values } \\
\hline \multicolumn{6}{|c|}{ No significant differences } \\
\hline \multicolumn{6}{|c|}{$\begin{array}{l}\text { EDUCATIONAL BACKGROUND } \\
(\text { G1 = Business/Economics; } n=111 ; G 2=\text { Engineering; } n=68)\end{array}$} \\
\hline \multicolumn{6}{|l|}{ Practices } \\
\hline a. Collectivism II & 3.67 & 1.499 & 3.49 & 4.01 & $\begin{array}{l}2.285 \\
(0.024)\end{array}$ \\
\hline b. Assertiveness & 3.56 & 1.046 & 3.77 & 3.41 & $\begin{array}{l}(-) 2.204 \\
(0.029)\end{array}$ \\
\hline \multicolumn{6}{|l|}{ Values } \\
\hline No significant diffe & & & & & \\
\hline
\end{tabular}




\begin{tabular}{|c|c|c|c|c|c|}
\hline \multicolumn{6}{|c|}{$\begin{array}{l}\text { SENIORITY IN MANAGEMENT POSITIONS } \\
(G 1=1-10 \text { yrs; } n=172 ; G 2=>10 \text { yrs; } n=44)\end{array}$} \\
\hline \multicolumn{6}{|c|}{ Practices } \\
\hline a. Collectivism II & 3.67 & 1.499 & 3.54 & 4.20 & $\begin{array}{l}(-) 2.634 \\
(0.009)\end{array}$ \\
\hline \multicolumn{6}{|l|}{ Values } \\
\hline a. Future Orientation & 4.06 & 1.541 & 3.95 & 4.48 & $\begin{array}{l}(-) 2.068 \\
(0.040)\end{array}$ \\
\hline b. Power Distance & 3.69 & 1.204 & 3.80 & 3.25 & $\begin{array}{l}2.770 \\
(0.006)\end{array}$ \\
\hline c. Humane Orientation & 3.62 & 1.451 & 3.50 & 4.07 & $\begin{array}{l}(-) 2.366 \\
(0.019)\end{array}$ \\
\hline $\begin{array}{l}\text { d. Performance } \\
\text { Orientation }\end{array}$ & 4.25 & 1.664 & 4.10 & 4.86 & $\begin{array}{l}(-) 2.742 \\
(0.007)\end{array}$ \\
\hline e. Collectivism II & 4.68 & 1.280 & 4.56 & 5.16 & $\begin{array}{l}(-) 2.854 \\
(0.005)\end{array}$ \\
\hline
\end{tabular}

* 2 - tailed significance; only statistical significant $(\mathrm{p}<0.05)$ differences are shown

As for differences between genders, the results show one significant difference in practice perception: Collectivism $\mathrm{I}(\mathrm{t}=2.416$; $\mathrm{sig}=0.017)$. Although both sub samples give lower scores than the scale middpoint, men consider Romanian society encourages and rewards the collective distribution of resources and collective action in a higher degree than women. With respect of groups expectations, females desire a higher Gender Egalitarianism in Romanian society $(\mathrm{t}=3.434$; sig $=0.001)$.

An interesting finding concerns the lack of significant differencess between age groups (up to 40 years and, respectivelly, more than 40 years old) both in assessing the societal practices and in expressing their expectations.

Between the types of educational background for managers (business or engineering), the results show two significant differences in practice perception: Collectivism II (engineers considering the family and groups as having higher importance in Romanian society) and Assertiveness (with engineers perceiving a lower assertiveness in our society than the managers with business education). No significant differences were shown for cultural expectations of the two groups.

Seniority in management positions led to one significant difference in practice perceptions, with the subjects having more than 10 years of managerial experience giving higher mean score for Collectivism II than those having up to 
10 years experience in such positions $(t=2.634$; $\mathrm{sig}=0.009)$. Finally, this demographic characteristic shows significant differences for five out of nine cultural expectations: Future Orientation, Power Distance, Humane Orientation, Performance Orientation and Collectivism II. The highest difference is recorded for Collectivism II, with the managers having more than 10 years in management positions desiring even tighter bonds within family and membership groups.

\section{Differences in perceptions: students vs. middle managers}

Table 5 lists the significant differences between students and middle managers with respect to societal culture practices, while the differences between the mean values of perceptions on cultural practices are displayed in Figure 4.

Table 5: Significant differences between the mean scores of societal practices: students vs. middle managers*

\begin{tabular}{|l|c|c|c|c|}
\hline $\begin{array}{l}\text { Cultural practice } \\
\text { ("society as it is") }\end{array}$ & Students & $\begin{array}{c}\text { Middle } \\
\text { managers }\end{array}$ & $\begin{array}{c}\text { Absolute } \\
\text { differences }\end{array}$ & $\begin{array}{c}\text { t-test } \\
\text { (sig 2-tailed) }\end{array}$ \\
\hline Uncertainty Avoidance & 3.49 & 3.92 & -0.43 & $\begin{array}{c}-5.124^{* *} \\
(0.000)\end{array}$ \\
\hline Future Orientation & 3.44 & 3.41 & 0.03 & $(0.673)$ \\
\hline Power Distance & 5.81 & 4.06 & 1.75 & $\begin{array}{c}16.608^{* *} \\
(0.000)\end{array}$ \\
\hline $\begin{array}{l}\text { Collectivism I } \\
\text { (Institutional) }\end{array}$ & 3.78 & 3.73 & 0.05 & $(0.469)$ \\
\hline Humane Orientation & 3.83 & 4.04 & -0.21 & $\begin{array}{c}-2.877 \\
(0.004)\end{array}$ \\
\hline $\begin{array}{l}\text { Performance } \\
\text { Orientation }\end{array}$ & 3.66 & 3.92 & -0.26 & $\begin{array}{c}-2.695^{* *} \\
(0.007)\end{array}$ \\
\hline $\begin{array}{l}\text { Collectivism II } \\
\text { (In group /Family) }\end{array}$ & 5.13 & 3.67 & 1.46 & $\begin{array}{c}13.376^{* *} \\
(0.000)\end{array}$ \\
\hline Gender Egalitarianism & 3.99 & 3.86 & 0.13 & $\begin{array}{c}2.183 \\
(0.029)\end{array}$ \\
\hline Assertiveness & 3.51 & 3.56 & -0.05 & $(0.579)$ \\
\hline
\end{tabular}

*two independent samples; **egual variances not assumed 
Figure 4: Differences between perceptions of cultural practices: students $v$. middle managers (mean scores)

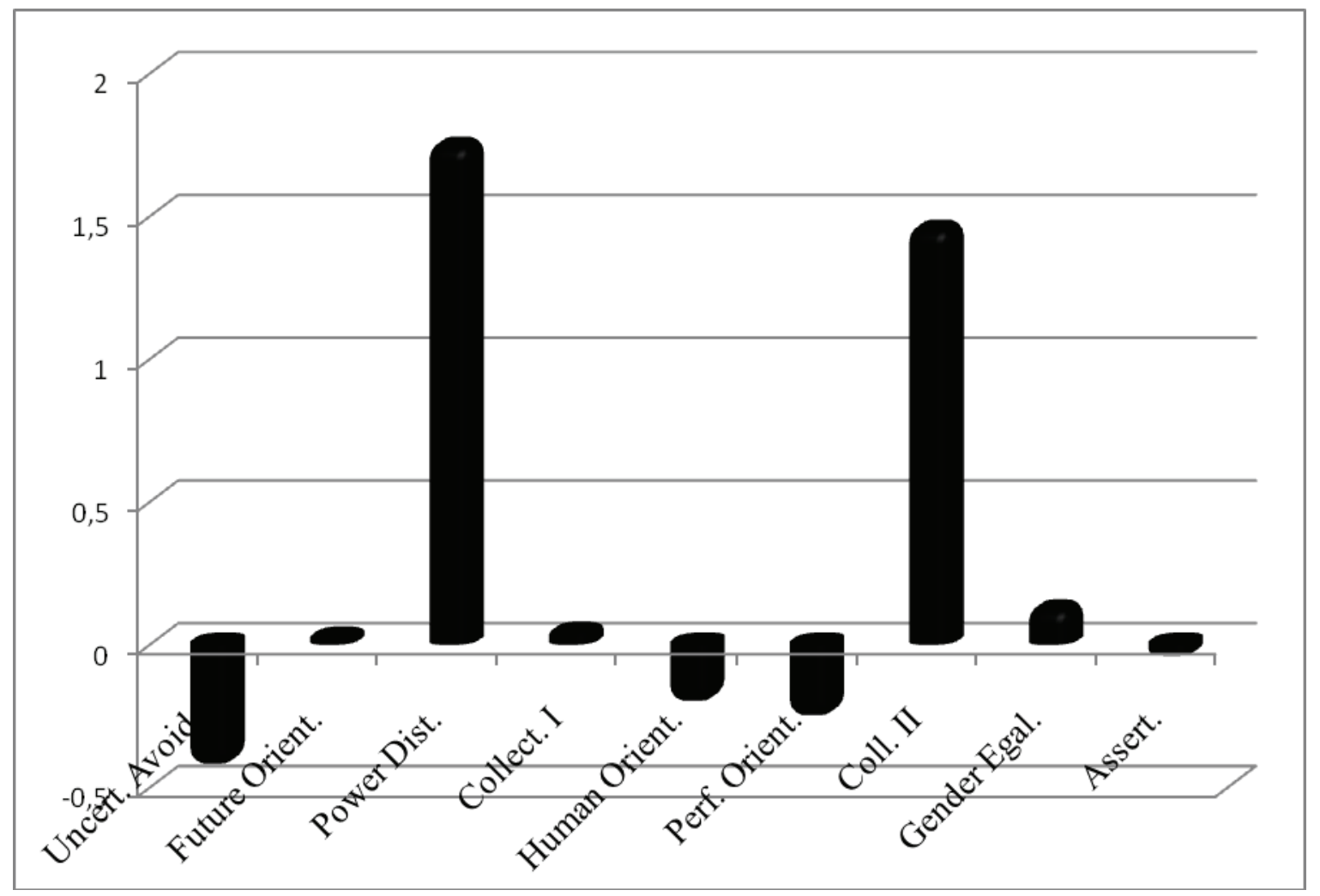

An examination of the t-tests between the mean scores (two independent samples) shows that the students perceived significanly higher values for Power Distance $(\mathrm{t}=16.608 ; \mathrm{sig}=0.000)$ and In group/Family Collectivism $(\mathrm{t}=$ 13.376; sig $=0.000$ ) than the managers (equal variaces not assumed). At the same time, the students perceived significantly lower mean values for Uncertainty Avoidance $(\mathrm{t}=5.124$; sig $=0.000)$, Humane Orientation $(\mathrm{t}=2.877$; sig $=0.004$; egual variances assumed $)$ and Performance Orientation $(\mathrm{t}=2.695$; sig $=0.007)$. The lack of significant differences for Future Orientation, Institutional Collectivismism and Assertiveness might be interpreted as sign of "enduring" cultural practicies in Romanian society.

\section{Differences in expectations: students vs. middle managers}

The data in Table 6 summarizes the significant differences between the cultural values that were most appreciated by the two groups, while Figure 5 shows the differences between the average scores of of the compared samples in terms of cultural expectations (values). 
Table 6: Significant differences between mean scores of societal values: students vs. middle managers*

\begin{tabular}{|l|c|c|c|c|}
\hline $\begin{array}{l}\text { Cultural value } \\
\text { ("society as it should } \\
\text { be") }\end{array}$ & Students & $\begin{array}{c}\text { Middle } \\
\text { managers }\end{array}$ & $\begin{array}{c}\text { Absolut } \\
\text { differences }\end{array}$ & $\begin{array}{c}\text { t-test } \\
\text { (sig 2-tailed) }\end{array}$ \\
\hline Uncertainty Avoidance & 5.10 & 3.58 & 1.52 & $\begin{array}{l}13.669 \\
(0.000)\end{array}$ \\
\hline Future Orientation & 5.23 & 4.06 & 1.17 & $\begin{array}{c}10.301 \\
(0.000)\end{array}$ \\
\hline Power Distance & 2.65 & 3.69 & -1.04 & $\begin{array}{c}-11.558 \\
(0.000)\end{array}$ \\
\hline $\begin{array}{l}\text { Collectivism I } \\
\text { (Institutional) }\end{array}$ & 4.94 & 4.17 & 0.77 & $\begin{array}{c}9.739 \\
(0.000)\end{array}$ \\
\hline Humane Orientation & 5.41 & 3.62 & 1.79 & $\begin{array}{l}16.978 \\
(0.000)\end{array}$ \\
\hline Performance Orientation & 5.89 & 4.25 & 1.64 & $\begin{array}{c}13.867 \\
(0.000)\end{array}$ \\
\hline $\begin{array}{l}\text { Collectivism II } \\
\text { (In group /Family) }\end{array}$ & 5.70 & 4.68 & 1.02 & $\begin{array}{c}10.512 \\
(0.000)\end{array}$ \\
\hline Gender Egalitarianism & 4.42 & 4.49 & -0.07 & $(0.130)$ \\
\hline Assertiveness & 4.01 & 4.08 & -0.07 & $(0.249)$ \\
\hline
\end{tabular}

* two independent samples; equal variances not assumed 
Figure 5: Differences between cultural expectations: students vs. middle managers (mean scores)

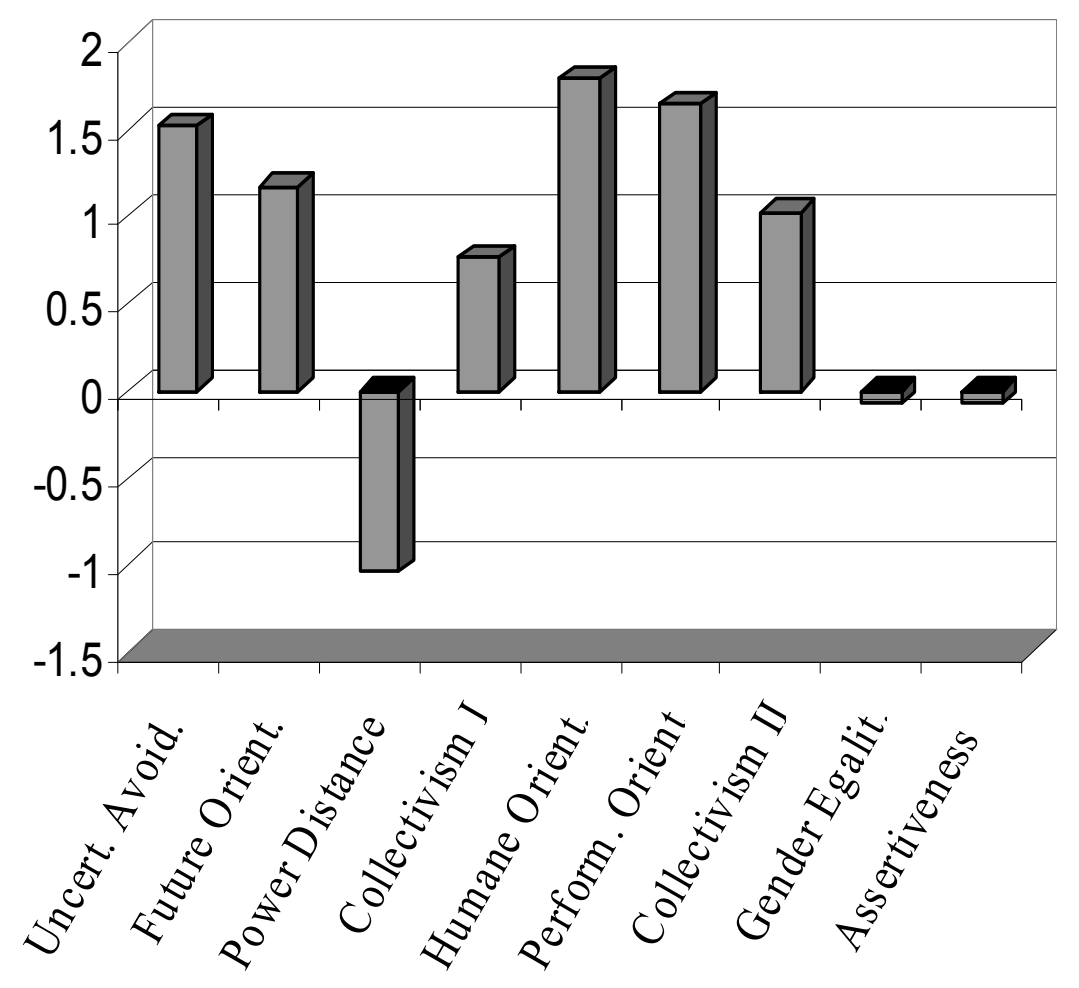

As the data show, there is no siginificant difference between the mean scores of the two samples concerning their expectations about Gender Egalitarianism and Assertiveness. However, the data reveal that Romanian students expect significantly higher levels of Humane Orientation $(t=16.978$; sig $=0.000)$, Performance Orientation $(\mathrm{t}=13.867$; sig $=0.000)$, Uncertainty Avoidance $(\mathrm{t}=$ 13.669; sig $=0.000)$, Collectivism II $(\mathrm{t}=10.512 ; \mathrm{sig}=0.000)$, Future Orientation $(\mathrm{t}=10.301$; sig $=0.000)$, and Collectivism $\mathrm{I}(\mathrm{t}=9.739$; $\mathrm{sig}=0.000)$. The students showed significantly lower expectations for Power Distance $(\mathrm{t}=$ 11.558; sig $=0.000$ ). Given these findings, it can be argued that equal treatment of men and women, as well as a stronger Assertiveness in defending/arguing own position represent the cultural foundation linking the future generation of managers with the present one.

\section{Discussions}

The following discusions focus on the most relevant differences between the compared mean values of the two samples. 


\section{Differences in perceptions: students and middle managers}

Our findings show that although both samples perceive Power Distance as the most prominent cultural practice (highest mean values: 5.81 in the students sample, 4.06 in the managers sample), the difference between their respective ratings produced the highest statistically significant difference. The mean value of the students sample confirms Hofstede's estimated index of Power Distance in Romania (90; Hofstede/Hofstede, 2005). The Power Distance surplus is the most important cultural pressure perceived by students in Romanian society. Practice/value ratio (2.19) shows that students perceive in the present societal structures a Power Distance twice higher than the norm desired by them: (expectation mean $=2.65$ ). This high Power Distance could find its explanation in Romanian tradition of power centralization at the level of some elites, both at macro and micro level (Catana/Catana, 2010). Students desire power decentralization and delegation, processes which they did not feel as having taken place in the last 20 years of democratic experience in Romania. On the other side, this cultural pressure is much lower in the case of managers (practice/value ratio $=1.1$ ), which means that Power Distance is regarded by them as tolerable. Should be noticed that previous studies shown a dual perception of managers on Power Distance: an acceptable distribution of power inside the company, but not at societal level (Catana/Catana 2010). The causes of this dual perception demand future qualitative research.

Both samples agree that Romanian society displays and practices relatively low levels of Future Orientation (mean values: students, 3.44; managers 3.41), Institutional Collectivism (students, 3.78; managers, 3.73) and Assertiveness (mean values: students, 3.51; managers, 3.56). From students perspective, the mean values of Future Orientation and Assertiveness are consistent with the other countries which make up the Eastern Europe cluster (3.37 for Future Orientation and respectivelly, 3.88), while the mean value of Institutional Collectivism is consistent with that of band $C$ group of countries (low Institutional Collectivism, ie. individualistic) in GLOBE research (House et al. 2004: 303-306; 467-472; 409-411).

The second highest significant difference in students and managers perceptions concerns the cultural dimension of Collectivism II (In group/Family Collectivism) in which, the students perceive tighter family and affiliative group bonds than the managers. The students' mean score is similar with the GLOBE research world average, while the score for middle managers places Romanian society among the countries with the lowest mean scores in the 61 societies analysed in GLOBE research (House et al. 2004: 467-472). For a more detailed discussion, one might invoke the fact that students are more groupist than managers. Compared with the managers, the students belong to more reference groups (school, friends, student organizations, political, sport, cultural, 
religious, funds etc. organizations). Or, as it is known, for the younger, group norms precede the social ones (laws, customs, advices, rules). Moreover, at least until their professional and social achievement, the students get the most important support from their families. A study shows that $79.6 \%$ of Romanians believe that the parents do their best for their children, $85.8 \%$ believe the family is very important institution in life and $71.7 \%$ consider friends as very and rather important in life (European Values Study 2009).

The student sample also showed a lower level of Uncertainty Avoidance ( $\mathrm{t}=$ 5.655 ; sig $=0.000$ ) suggesting that they perceive their society does not pay enough attention to creating a stable legal, political and economic environment or to long term planning. The high estimated index of Uncertainty Avoidance in Romania (90; Hofstede/Hofstede 2005; Luca 2005) is an artifact of the socialist era during which managers worked in a culture with a very high Uncertainty Avoidance. Our finding in terms of the students perception of Uncertainty Avoidance (3.49) places Romania in "band" C-D of GLOBE study, close to countries such as Georgia (3.50), Venezuela (3.44) and Greece (3.39), confronted with high level of uncertainty in their daily lives (House et al. 2004: 622). The middle managers perception on this cultural practice is similar with levels found in Thailand (3.92) and the Arabic cluster average (3.91) (House at all, 2004: 621-623), reflecting a perception that their lives are framed by laws, rules and regulations.

\section{Differences in expectations: students and middle managers}

The student sample displayed higher mean values for six out of the nine cultural expectations (Table 6). The two samples are very similar in their desire concerning the Romanian society orientation towards Gender Egalitarianism and Assertiveness. These two cultural values might reveal the foundation (continuity) on which the Romanian future managers will operate.

The most significant positive difference between the samples was noted for Humane Orientation $(\mathrm{t}=16.978$; sig $=0.000$; equal variances not assumed $)$ where the students exhibited a stronger desire for their society to encourage and reward fairness, altruism, friendship, generosity and kindness. This means that in the students' mind, the current level of social humanism is still below the norm. This is naturally linked to students having grown up in the transition period from a totalitarian to a democratic society, from centralized to market economy, being surrounded by selfishness, individualism, a rush for fortune, competition and less humanism.

Of similar interest are the significant higher mean scores for student expectations in terms of Performance Orientation and Uncertainty Avoidance (equal variances not assumed in both cases). These findings are different from those discovered when comparing Austrian and Irish students with middle managers in their respective societies (Keating et al. 2002). The expectations of 
middle managers concerning Performance Orientation are higher in Austria and Ireland (6.10 and 5.98 respectively) than of Romanian ones (4.25). While smaller in degree, this trend was also noted for Uncertainty Avoidance, the scores in Austria (3.66) and Ireland (4.02) exceeding the expectations in Romania (3.58). The student samples scores for Performance Orientation were closer in the three countries: 6.06 in Austria, 5.89 in Ireland and Romania. In terms of Uncertainy Avoidance, the expectations of Romanian students sample was much higher than was noted for their counterparts in Austria and Ireland ( 5.10 vs. 3.65 and 3.78 respectively). Finally, the gap between the students and middle managers in their expectations regarding Performance Orientaiton was found to be much lower in Austria and Ireland than in Romania (- 0.04 in Austria, -0.09 in Ireland, +1.64 in Romania). The same was found for Uncertainty Avoidance (- 0.01 in Austria, -0.24 in Ireland and +1.52 in Romania) (Keating et al, 2002: 647).

Although both students and middle managers perceive Power Distance as the most identifiable cultural feature of our society (highest mean scores for practice in both samples), the students have a clear desire for a significantly lower Power Distance than the middle managers (2.69 vs. 3.69; gap: $-1.04 ; \mathrm{t}=$ 11.558 ; sig $=0.000$; equal variances not assumed). The lower gap between what the middle managers have (practice) and expect (value) in the field of Power Distance (0.37 compared with 3.16 for students) might be attributable to a feeling that the current power arrangements cannot be changed dramatically since the social bodies endowed with power decide as their personal interests dictate, and in doing so, pretend not to neglect the interests of unions and opposing political parties.

If we look at the gap between Austrian and Irish students and middle managers in their desire for a lower Power Distance, we find much lower values than in Romania (- 0.21 in Austria; - 0.32 in Ireland; - 1.04 in Romania) (based on Keating et all, 2002: 647). These lower values show a trend toward convergence in the two compared samples from expected Power Distance perspective (Austria and Ireland). 


\section{Conclusions}

Our research findings offer specific answers to the research questions:

1. The Romanian students in business and engineering show significant differences between societal cultural practices and expectations (values) for all nine cultural dimensions, with the highest desire being to reduce the Power Distance and increase Performance Orientation and Uncertainty Avoidance. Although institutional theory suggests that changes in the more culturally embedded elements of management seem to be more difficult to achieve (Lang/Steger 2002), the fact that the prospective future managers assign different levels of importance to these societal values leads us expect that they will act to change their cultural environments.

2. The middle managers exhibited significant differences between societal cultural practices and expectations for all nine cultural dimensions. They shown a desire for more Family Collectivism, Gender Egalitarianism, Future Orientation, Assertiveness, Institutional Collectivism and Performance Orientation. On the other side, the middle managers expect less Uncertainty Avoidance, Power Distance, and Humane Orientation.

3. No siginficant differences were found between students and managers in assessing the practice of Future Orientation, Institutional Collectivism and Assertiveness. Significantly higher mean scores among students were found to exist for Power Distance, Family Collectivism and Gender Egalitarianism.

4. The value system held by Romanian prospective future managers and current middle managers showed evidence of similarities in expectations concerning Gender Egalitarianism and Assertiveness. Significantly higher mean scores among the students were found to exist for Humane Orientation, Performance Orientation, Family Collectivism, Uncertainty Avoidance, Future Orientation and Institutional Collectivism.

Overall, our findings show that changes will occur in Romanian societal culture dimensions, as compared samples expressed same expectation for a society concerned with higher Future orientation, Institutional collectivism, Performance orientation, In group/Family collectivism II, Gender egalitarianism and Assertiveness and with much lower Power Distance.

We are aware that our research findings are conditional on a number of assumptions and data limitations, among which: that business and engineering students will form a core component in the future population of managers; different sample sizes; different periods of data collection; the fact that national culture may not fully overlap with the societal/ethnic culture(s) of its inhabitants; dominance of quantitative instruments. 
Beyond the limitations, we believe that our findings offer certain insights into relevant issues of societal practices and values for researchers, academics and consultants in management and leadership, as well as for today's practitioners.

Future research should focus on studying cultural practices and value systems in directions like the impact of socialization agents on students' perceptions and expectations and comparisons with other countries taking part to GLOBE student project.

\section{References}

Catana, Gh. A./ Catana, D. (2010): Organizational culture dimensions in Romanian finance industry, in: Journal for East European Management Studies, 15, 2, 128-148.

Chhokar, S. J./ Brodbeck, C. F./ House, J. R. (eds.), (2007): Culture and Leadership Across the World: The GLOBE book of in-depth studies of 25 societies. New York: Lawrence Erlbaum Associates Publishers.

Ferraro, G. P. (1994): The cultural dimension of international business (2nd ed.). Englewood Cliffs: Prentice-Hall.

Hofstede, G. (1980): Cultures consequences: International differences in work related values. London: Sage.

Hofstede, G./ Hofstede G. J. (2005): Cultures and organizations. Software of the Mind, $2^{\text {nd }}$ Edition. New York: Mc Graw-Hill.

House, R./ Javidan, M./ Hanges, P./ Dorfman, P. (2002): Understanding cultures and implicit leadership theories across the globe: an introduction to project GLOBE, in: Journal of World Business, 37, 3-10.

House, R. J./ Javidan, M./ Dorfman, P.W./ Gupta, P.W. (eds.). (2004): Culture, leadership, and organizations: The GLOBE study of 62 societies. Thousand Oaks: Sage.

Keating, A. M./Martin, S. G./ Szabo, E. (2002): Do managers and students share the same perceptions of societal culture? in: International Journal of Intercultural Relations, 26, 633 -652 .

Kluckhohn F.R./ Strodtbeck, F. L. (1961), Variations in value orientations. New York: Harper Collins.

Lang, R./ Steger, T. (2002): The odyssey of management knowledge to transforming societies: A critical review of a theoretical alternative, in: Human Resource Development International, 5, 279-294.

Luca, A. (2005), Studiu despre valorile si comportamentul romanesc din perspectiva dimensiunilor culturale dupa metoda lui Geert Hofstede, INTERACT. Available at http://anatolbasarab.files.wordpress.com/2010/05/studiu_hofstete5.pdf

McClelland, D. C. (1985): Human motivation. Glenview: Scott, Foresman.

Putnam, R. D. (1993): Making democracy work. Princeton: Princeton University Press.

Triandis, H. C. (1993): Collectivism and individualism as cultural syndromes, in: CrossCultural research, 27, 3\&4, 155-180. 
Williams, R. M. (1979): Change and stability in values and value systems: A sociological perspective, in: Rokeach, M. (ed): Understanding values. New York: Free Press, 15-46.

European and World Values Surveys four-wave integrated data file, 1981-2004, v.20060423, 2006. Surveys designed and executed by the European Values Study Group and World Values Survey Association. File Producers: ASEP/JDS, Madrid, Spain and Tilburg University, Tilburg, the Netherlands. File Distributors: ASEP/JDS and GESIS, Cologne, Germany, available at: http://www.jdsurvey.net/evs/EVSAnalizeQestion.jsp 